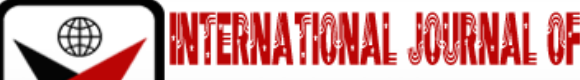

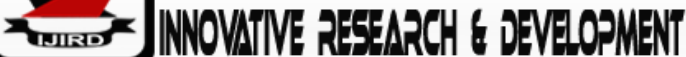

ISSN 2278-0211 (Online)

\section{Financial System Development in Emerging Economies: An Array of BRICS Economic Bloc}

Ukpabi Innocent O.
Ph.D. Research Student, Department of Banking and Finance,
University of Nigeria Nsukka, Enugu Campus, Nigeria
OnuCalistus
Ph.D. Research Student, Department of Banking and Finance,
University of Nigeria Nsukka, Enugu Campus, Nigeria
Eleje Emmanuel C.
Ph.D. Research Student, Department of Banking and Finance
University of Nigeria Nsukka, Enugu Campus, Nigeria

\begin{abstract}
:
The study examined financial system development in emerging economic bloc of Brazil, Russia, India, China and South Africa (BRICS) with a view to ascertaining the level of financial institutions and markets depth, access and efficiency and intra-dependency of these financial system development indicators in member countries from 2000-2020. Comparatively, the level financial institutions and markets depth, access and efficiency in some BRICS member countries were below standards for emerging economies while some performed above the benchmark.VAR results revealed that indicators of financial system development were strongly endogenous and exogenous in the short and long run, depictingindependent influence and significant self-predictions. Based on the findings, researchers recommends that BRICS monetary zone should be established to facilitate cross border effect of financial institutions and markets development in member states, monetary authoritiesof BRICS should establish financial system development secretariat to harness the component influence of financial institutions and markets depth, access and efficiency in her member countries and to pursue a robust financial institutions and markets development framework to complement innovations in the different components of the financial system and provide incentives forthe adoption of digital financial system in heremerging economic bloc.
\end{abstract}

Keywords:Financial system development, emerging economies, BRICS economic bloc

\section{Introduction}

Developing countries herald common frontier to emancipate her economic throes by forming blocs to foster economic integration beyond regional and sub-regional organizations. This holistic deal of economic transformationby emerging market giants like Brazil, Russia, India, Chi BRICS hugged on her establishment and expansion of financial institutions, instruments and markets to facilitate multilateral trade,economicgrowth processes and sustain tempo. However, financial system development witnessed colossal dynamism brought by financial innovations and poseas a global phenomenon for virile economy which has beenempirically and theoretically explored, relegating financial system development measures in thecontemporary issues, as existing intellectual contest focused mainly on the matrix of financial sector development and economic performance indicators with no attention on the symbiotic interactionsamong financial system development indicators in the emerging markets and economic blocs. Consequently, this study examines financial system development in emerging economic bloc of BRICS with a view to ascertaining intra dependence of financial institutions and markets depth, access and efficiency in member countries.

\section{Literature Review}

The financial system plays central role in an economy especially in the emerging market giants such as Brazil, Russia, India, China and South Africa (BRICS). Financial systemdevelopment thus involves the establishment and expansion of financial institutions, instruments and markets which supports the investment and growth process through improvements in the quantity, quality and efficiency of financial intermediary services Osuji (2015).According to Ronoh and Omwenga (2017), the developments in the financial sector have not only led to the increase in the number of financial institutions, but also the development in level of sophistication with new payment systems and asset alternatives to holding money. However, Stiglingh, Muzindutsi and Bezuidenhout (2018) aver that there seems to be a lack of strong financial system and policies to deliver the required economic results in most developing countries.Iheonu et al (2020)collaborate thatdevelopment of the financial sector enhances efficient access to financial services and products. 


\subsection{Financial System Development in BRICS}

Figure s 2.1, 2.2 and 2.3 below presents the level of financial institutions depth (FID), access (FIA), efficiency (FIE) compared to the international monetary fund (IMF)bench mark (B/Mark) for emerging economies across the globe.WhileFigure 2.4, 2.5 and 2.6 presents financial markets depth (FMD), access (FMA), efficiency (FME) also compared to thebench mark for emerging economies in BRICS countries.

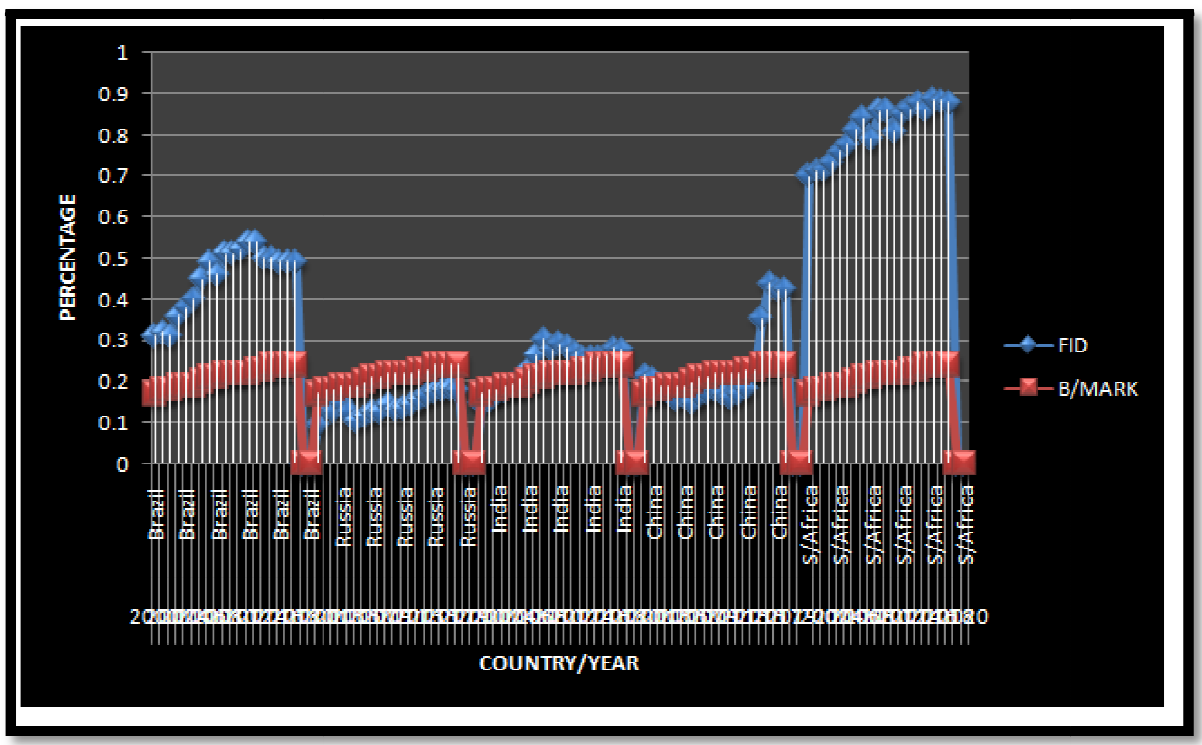

Figure 1: FinancialInstitutions Depth(FID) in BRICS and Emerging Markets Bench Mark (B/Mark)

Figure 1 above reveals that the ratio of financial system depth (FID) in Brazil ranges from $0.31 \%$ to $0.54 \%, 0.10 \%$ to $0.18 \%$ in Russia, $0.15 \%$ to $0.30 \%$ in India, $0.15 \%$ to $0.44 \%$ in China and $0.71 \%$ to $0.88 \%$ in South Africa compared to $0.17 \%$ to $0.24 \%$ IMF bench mark for emerging markets with 21 years average ratio of $0.45 \%, 0.14 \%, 0.24 \%, 0.23 \%$ and $0.81 \%$ for Brazil, Russia, India, China and South Africa respectively, allabove $0.21 \%$ annual averagebench mark within the period.The annual FID in Braziland South Africa wereall above IMF bench mark throughout the period, while reverse was the case inRussia. Apart from 2000 and 2001 below bench mark for emerging markets, 2002 and 2004 equality, India FID wasabove bench mark within the time under review. China's annually ratios were below theminimum standard except in 2000, 2001, 2002, 2017 and 2018.

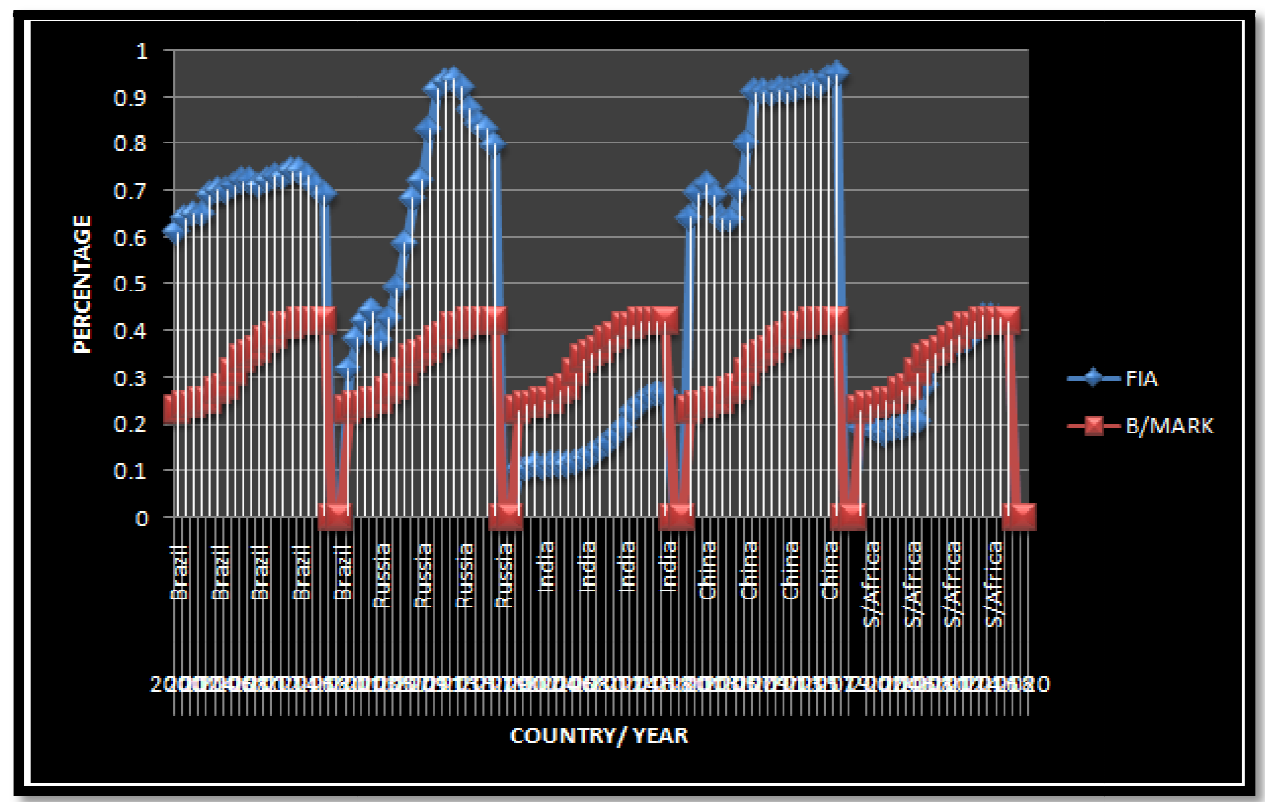

Figure 2: Financial Institutions Access (FIA) in BRICS and Emerging Markets Bench Mark(B/Mark)

Figure 2 above depicts that the ratios of financial system access (FIA) in Brazil , Russan and China are above the IMF annual bench marks throughout the period with annual average of $0.70 \%, 0.67 \%$ and $0.77 \%$ compared to annual average $0.34 \%$ bench mark for emerging markets and a range of $0.61 \%$ to $0.74 \%$ in Brazil, $0.32 \%$ to $0.94 \%$ in Russia and $0.64 \%$ to $0.95 \%$ in China. While, FIA ratios in India and South Africa were below the IMF bench marks within the period under review with annual average of $0.16 \%$ and $0.30 \%$ for India and South Africa and respective range of $0.10 \%$ to $0.26 \%$ and $0.18 \%$ to $0.42 \%$ except for South Africa equalities in 2010, 2011, 2017 and 2018 and slight records above bench mark in 2014, 2015 an d 2016. 


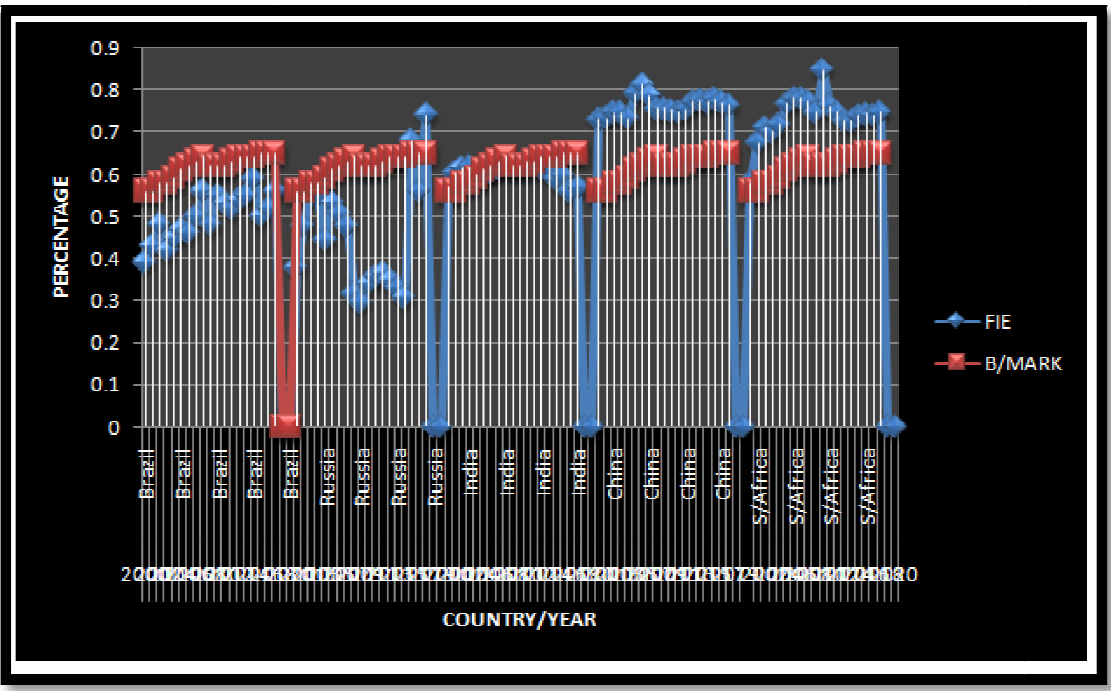

Figure 3: Financial Institutions Efficiency (FIE) in BRICS and Emerging Markets Bench Mark (B/Mark)

Figure 3 above revealed that ratios of financial system efficiency (FIE) in China and South Africa outweighs the IMF bench mark throughout the period with annual average of $0.76 \%$ and $0.74 \%$ and range of $0.73 \%$ to $0.81 \%$ and $0.58 \%$ to $0.85 \%$ compared to $0.62 \%$ average annual benchmark with ranging from $0.56 \%$ to $0.65 \%$. Brazil, Russia and India performed sharply below the emerging markets standard throughout the period with annual average of $0.5 \%$, $0.45 \%$ and $0.60 \%$ respectively, with the exceptions of 2016 and 2018 in Russia, India's equalities in 2009, 2010 and 2012 and slightly above bench mark in 2000, 2001, 2002, 2003, 2004 and 2011. However, Brazil, Russia and India ratios ranges from 0.39\% to $0.59 \%, 0.30 \%$ to $0.74 \%$ and $0.57 \%$ to $0.63 \%$ respectively.

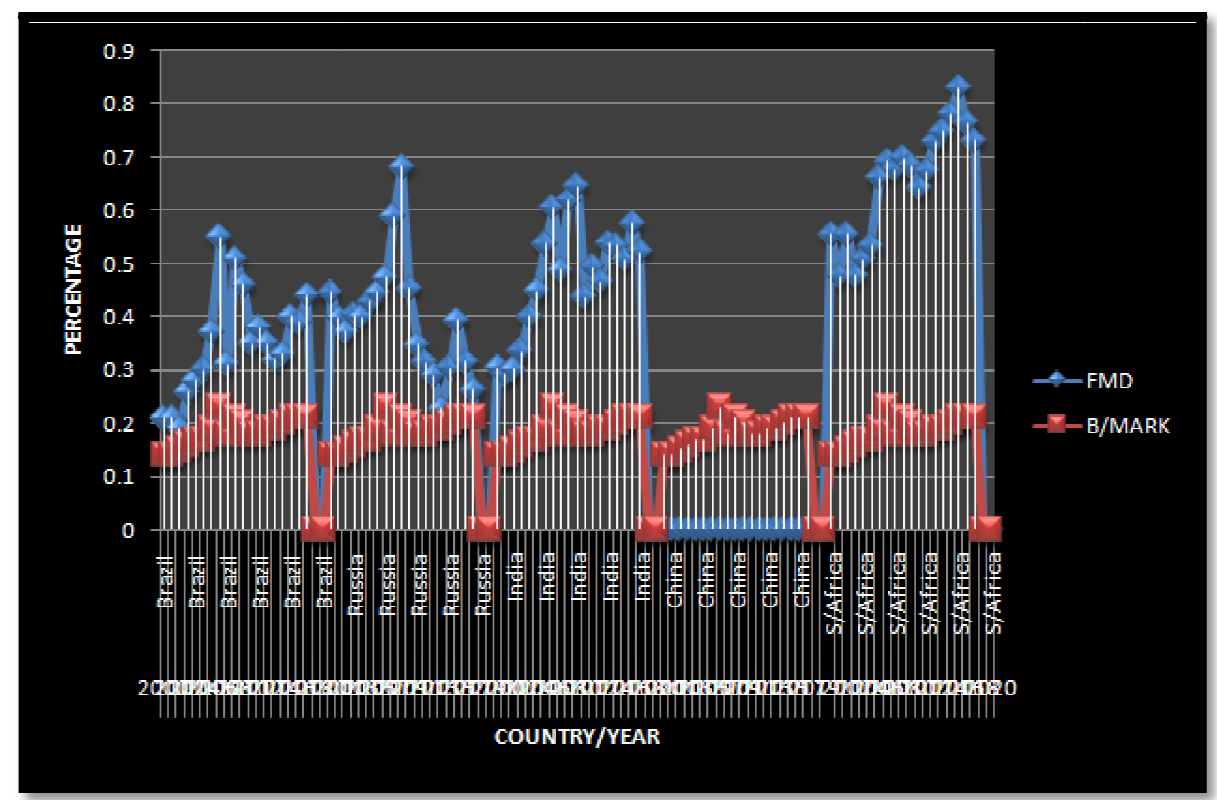

Figure 4: Financial Market Depth (FMD) In BRICS and Emerging Markets Bench Mark(B/Mark)

From Figure 4 above, the ratios of financial markets depth (FMD) in Brazil , Russia India and South Africa are higher than the IMF annual bench marks for emerging markets with annual average of $0.35 \%, 0.40 \%$ and $0.48 \%$ and $0.65 \%$ respectively compared to annual average standard of $0.18 \%$. A range of $0.19 \%$ to $0.55 \%$ was observed in Brazil, $0.26 \%$ to $0.68 \%$ in Russia, $0.29 \%$ to $0.65 \%$ in India and $0.48 \%$ to $0.83 \%$ in South Africa. While, FIA ratios in China was glaringly below bench mark by recording $0.00 \%$ throughout the period. 


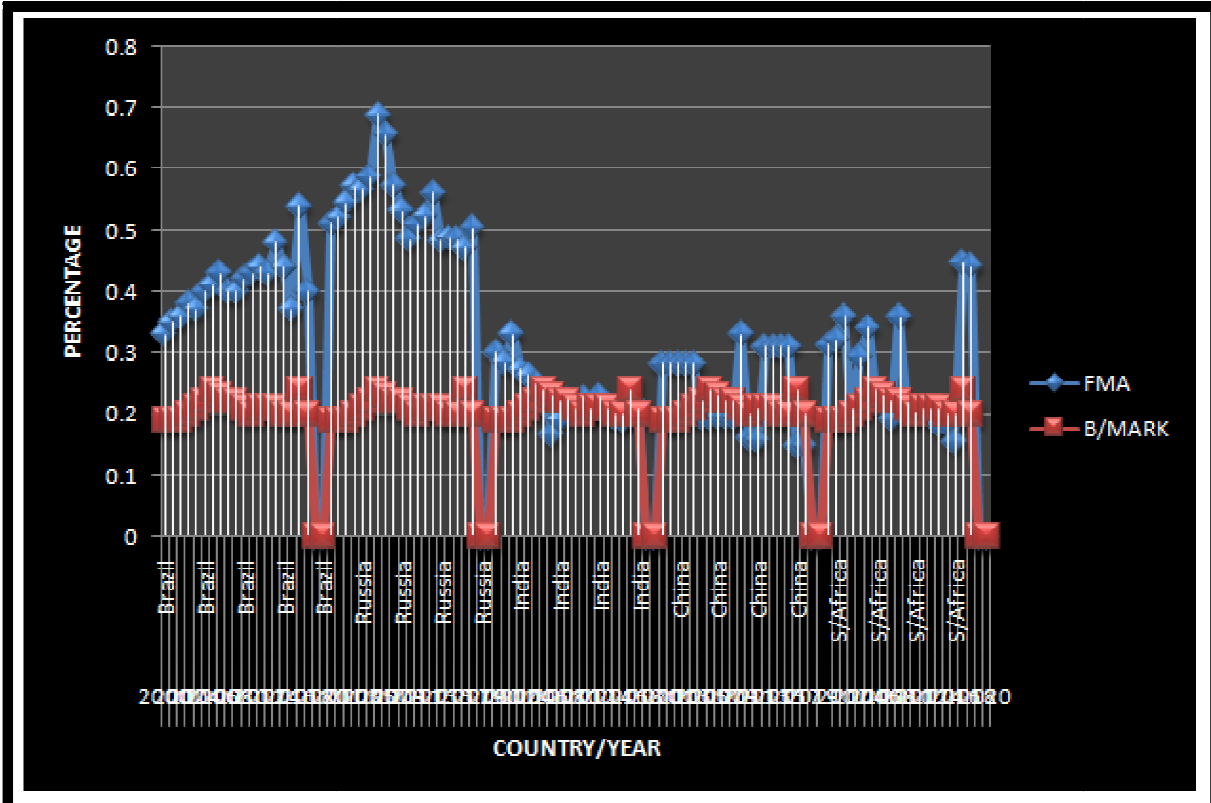

Figure 5:Financial Markets Access (FMA) in BRICS and Emerging Markets Bench Mark (B/Mark)

BRICS financial markets access in Figure 5 above shows that Brazil and Russia ratios were above the emerging markets standard throughout the period with annual average of $0.41 \%$ and $0.54 \%$ ranging from $0.33 \%$ to $0.54 \%$ and $0.47 \%$ to $0.69 \%$ respectively compared to IMF bench mark of $0.21 \%$ ranging from $0.19 \%$ to $0.24 \%$. While, ratios of India, China and South Africa were $0.23 \%, 0.24 \%$ and $0.27 \%$ with respective range $0.17 \%$ to $0.33 \%, 0.15 \%$ to $0.33 \%$ and $0.16 \%$ to $0.45 \%$. India ratios were above the standard except in 2007, 2008, 2014 and 2017 with equalities in 2006, 2009, 2010, 2012, 2015 and 2016. China's ratios were above the bench mark throughout the period except in 2005, 2006, 2007, 2008, 2009, 2011, 2012, 2017 and 2018. Apart from 2002 and 2012 equalities and 2008, 2013, 2014 and 2015 below standard, South Africa's ratios were above the bench mark.

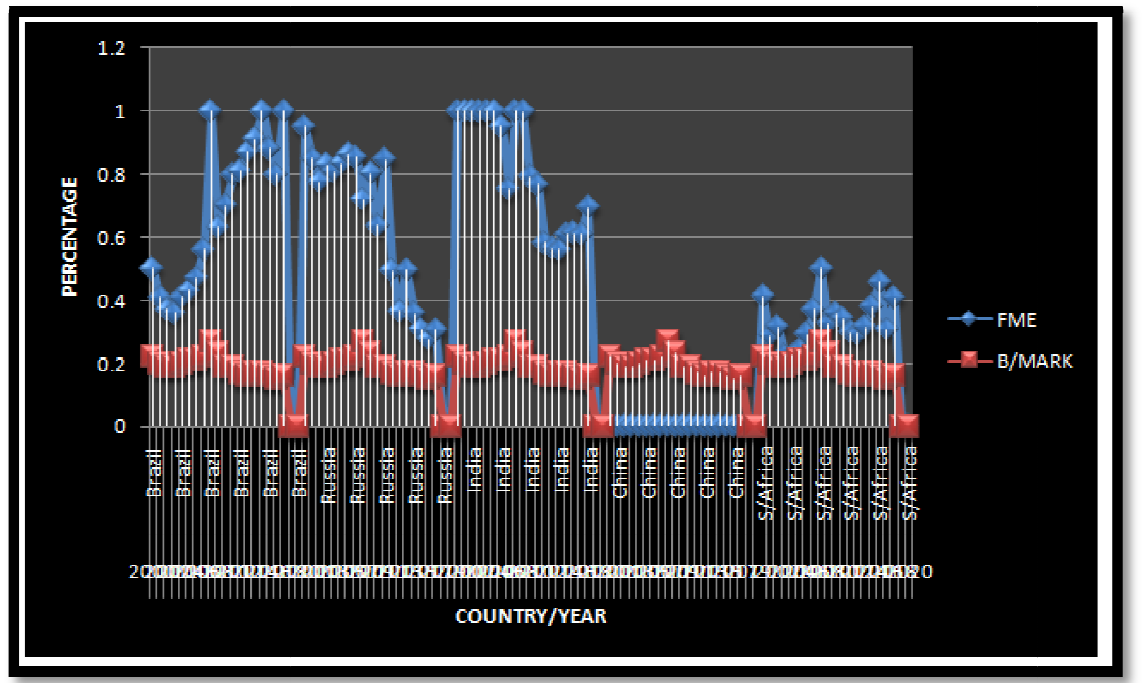

Figure 6: Financial Markets Efficiency (FME) in BRICS and Emerging Markets Bench Mark (B/Mark)

In Figure 6 above, BRICS countries recorded financial markets efficiency above minimum standard throughout the period except China that that had $0.00 \%$. The annual average ratios in Brazil, Russia, India and South Africa were $0.68 \%$, $0.65 \%, 0.81$ and $0.33 \%$ respectively above $0.19 \%$ average minimum bench mark for emerging markets. The ratios ranges from $0.5 \%$ to $0.91 \%$ in Brazil, $0.28 \%$ to $0.95 \%$ in Russia, $0.56 \%$ to $1.00 \%$ in India and $0.23 \%$ to $0.50 \%$ in South Africa, all above $0.15 \%$ to $0.27 \%$.

\subsection{Empirical Review}

Sulemana and Dramani (2020) conducted a comparative analysis of the effect of FSD on economic growthbetween Economic Community of West African States (ECOWAS) and Southern African Development Community (SADC). The results suggested the existence of FSD-led growth in SADC but revealed no statistically significant effect in ECOWAS. Furthermore, the effect of FSD through institutional development supported a positive complementarity effects on growth in both regions but only statistically significant in ECOWAS, suggesting strong institutions complemented FSD effects on growth.Iheonu et al. (2020) found among others that the impact of financial sector development on domestic investment 
depends on the measure of financial sector development utilized, banking intermediation efficiency and broad money supply negatively and significant influence domestic investment. Sarwar et al. (2020) study indicates that financial development has a positive and significant effect on economic growth. In emerging countries, human capital also has a positive impact on economic growth. Financial development and human capital interactively affect economic growth for emerging economies positively and significantly.Majumder, Ramalingam and Ramudu (2019) used panel vector auto regression modeling techniques and Impulse response functions to analyses howfinancial expansion boosts economic growth and vice versa. Findings revealed that economic progression drives production and that in turn develops financial sector, that even though stock market growthfor the MINT group is nascent, it contributes significantly to financial development. The dynamic behavior among thefinancial \& growth variables illustrate that a shock in broad money affects economic growth immediately for a shortperiod along with stock market.

Guru and Yadav (2019) used generalized method of moment system estimation examine the relationship between financial development and economic growth for five major emerging economies: Brazil, Russia, India, China and South (BRICS) during 1993 to 2014 using banking sector and stock market development indicators that banking sector development and stock market development indicators are complementary to each other in stimulating economic growth.Gokhale (2018) applied Jarque-Bera test, Kurtosis and Augmented Dickey Fuller to test the efficient market hypothesis in MINT nations. Mexico showed an inclination towards the efficient market, as the kurtosis was marginally leptokurtic and the probability of bubble formation could be low. Whereas Nigeria, Indonesia and Turkey failed to satisfy EMH as the stock market returns were substantially leptokurtic and even the probability of bubble formation could be comparatively higher for Nigeria and Indonesia than the other MINT nations.Stiglingh, Muzindutsi and Bezuidenhout (2018) used a balanced panel data analysis to investigate the relationship between financial development and economic growth using a sample of BRICS countries for the period of 1996 to 2016 and a long run and short run relationship between economic growth and financial development to some degree was found.

Mugova (2017) applied GMM estimation technique to investigate impact financial sector development on firm growth amongst3353 listed firms in BRICS. Results revealed that listed firms in Brazil, Russia India, China and South Africa had a target total liabilities-to-total assets ratio and financial sector development helps firms to partially adjust towards target levels and pursue growth opportunities.

\subsection{Theoretical Review}

Legal Theory of Finance (LTF) prostrates that in countries where legal systems enforce private property rights, support private contractual arrangements, and protect the legal right of investors, savers are more willing to finance firms and financial system flourish. According to Pistor (2013), the LTF posits that financial markets are constructed legally and ensconced in a hybrid location between market and state, private and public. Law is more fundamental to modern finance than recognized in the extant literature, It allocates power to regulators both private and public; offers authority to private and public financial instruments; and validates financial instruments generated from private contracts if they are consistent with the law (Sarpong and Deodutt, 2019). Arguably, law's significance to finance has increased with the transition from relational finance to entity and ultimately, market based finance. Financial instrument fungibility in anonymous markets depends on credible contractual commitments that can be legally enforced. La Porta et al. ( $\underline{1998})$ assert that protecting private contracting rights is fundamental to financial development. Pistor, (2013) argued that finance and law co-constituted and financial markets can be better understood through the lenses of the LTF, and the most important stylized facts of contemporary finance, both national and global are first, that financial assets are legally constructed; secondly law contributes to finance's instability; thirdly, there is a pecking order of the means of pay, which implies that finance is inherently hierarchical; and lastly, the binding nature of legal and contractual commitments tends to be inversely related to the hierarchy of finance: Law tends to be binding on the periphery and relativelymore elastic at the apex of the financial system.

\section{Methodology and Data Analysis}

As a result of endogenous model variables, the VAR approach was adopted as the most plausible technique of analysis in this study as the deals with dependent variables only. The VAR Models automatically specified thus:

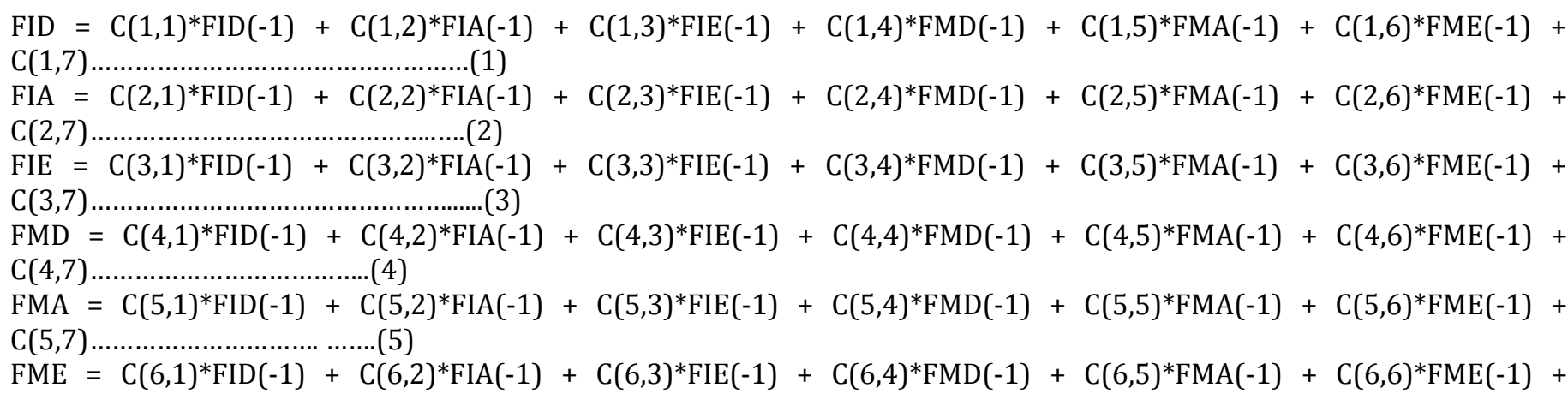

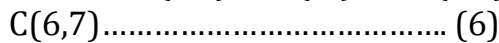




\begin{tabular}{|c|c|c|c|c|}
\hline Notation & Variable & Description & $\begin{array}{c}\text { Data } \\
\text { Source }\end{array}$ & $\begin{array}{c}\text { A'priori } \\
\text { Expectation }\end{array}$ \\
\hline FID & $\begin{array}{l}\text { financial } \\
\text { institutions } \\
\text { depth }\end{array}$ & $\begin{array}{c}\text { Bank credit to the private sector in } \\
\text { percentage of gross domestic product (GDP), } \\
\text { pension fund assets to GDP, mutual fund } \\
\text { assets to GDP, and insurance premium, life } \\
\text { and non life to GDP }\end{array}$ & IMF & $\begin{array}{l}\text { Strong } \\
\text { endogeneity and } \\
\text { exogeneity }\end{array}$ \\
\hline FIA & $\begin{array}{c}\text { financial } \\
\text { institutions } \\
\text { access }\end{array}$ & $\begin{array}{l}\text { Bank branches per } 100,000 \text { adult and ATMs } \\
\text { per } 100,000 \text { adults. }\end{array}$ & IMF & $\begin{array}{l}\text { Strong } \\
\text { endogeneity and } \\
\text { exogeneity }\end{array}$ \\
\hline FIE & $\begin{array}{l}\text { financial } \\
\text { institutions } \\
\text { efficiency }\end{array}$ & $\begin{array}{l}\text { Banking sector net margin, lending deposits } \\
\text { spread, non-interest income to total income, } \\
\text { overhead costs to total assets, return on } \\
\text { assets, and return on equity. }\end{array}$ & IMF & $\begin{array}{l}\text { Strong } \\
\text { endogeneity and } \\
\text { exogeneity }\end{array}$ \\
\hline FMD & $\begin{array}{l}\text { financial } \\
\text { markets } \\
\text { depth }\end{array}$ & $\begin{array}{c}\text { stock market capitalization to GDP, stock } \\
\text { traded to GDP, international debt securities of } \\
\text { government to GDP and total debt securities } \\
\text { of financial and non-financial corporations to } \\
\text { GDP }\end{array}$ & IMF & $\begin{array}{c}\text { Strong } \\
\text { endogeneity and } \\
\text { exogeneity }\end{array}$ \\
\hline FMA & $\begin{array}{l}\text { financial } \\
\text { markets } \\
\text { access }\end{array}$ & $\begin{array}{l}\text { Percentage of market capitalization outside of } \\
\text { top } 10 \text { largest companies and total number of } \\
\text { issuers of debt domestically and external, } \\
\text { financial and nonfinancial corporation per } \\
100,000 \text { adults }\end{array}$ & IMF & $\begin{array}{c}\text { Strong } \\
\text { endogeneity and } \\
\text { exogeneity }\end{array}$ \\
\hline FME & $\begin{array}{l}\text { financial } \\
\text { markets } \\
\text { efficiency }\end{array}$ & $\begin{array}{l}\text { Stock market turnover ratio (stocks traded to } \\
\text { capitalization). }\end{array}$ & IMF & $\begin{array}{c}\text { Strong } \\
\text { endogeneity and } \\
\text { exogeneity } \\
\end{array}$ \\
\hline
\end{tabular}

Table 1: Description of Model Variables

\begin{tabular}{|c|c|c|c|c|c|c|}
\hline $\begin{array}{l}\vec{E} \\
\text { J } \\
\text { 己 }\end{array}$ & 䆓 & 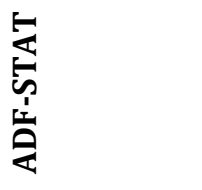 & 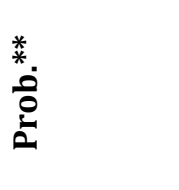 & 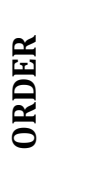 & $\coprod_{J}^{J}$ & 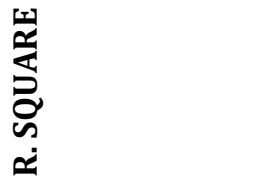 \\
\hline \multirow{6}{*}{$\frac{\sqrt{n}}{\frac{1}{\infty}}$} & FID & 39.2481 & 0.0000 & $1(1)$ & 1 & 0.989359 \\
\hline & FIA & 19.9951 & 0.0293 & $1(1)$ & 1 & 0.986763 \\
\hline & FIE & 21.1297 & 0.0202 & $1(0)$ & 1 & 0.837765 \\
\hline & FMD & 55.7496 & 0.0000 & $1(1)$ & 1 & 0.910786 \\
\hline & FMA & 66.2481 & 0.0000 & $1(1)$ & 1 & 0.775933 \\
\hline & FME & 58.7376 & 0.0000 & $1(0)$ & 1 & 0.899530 \\
\hline
\end{tabular}

Table 2: Summarized Results of Preliminary Analysis

Table 2 above summarized the panel unit root test, optimal lag structure and measure of regression. Positive values of the Augmented Dickey Fuller (ADF) statistic indicated stationarity of the variables, and confirmed by the probability values less than one each. FID, FIA, FMD andFMA integrated in order one, while FIE and FME attained stationarity at level form. Optimal lag structure of one was obtained across the variables and R square individual coefficients of determination shows the high degree of self-prediction by each variable tested in the model. 


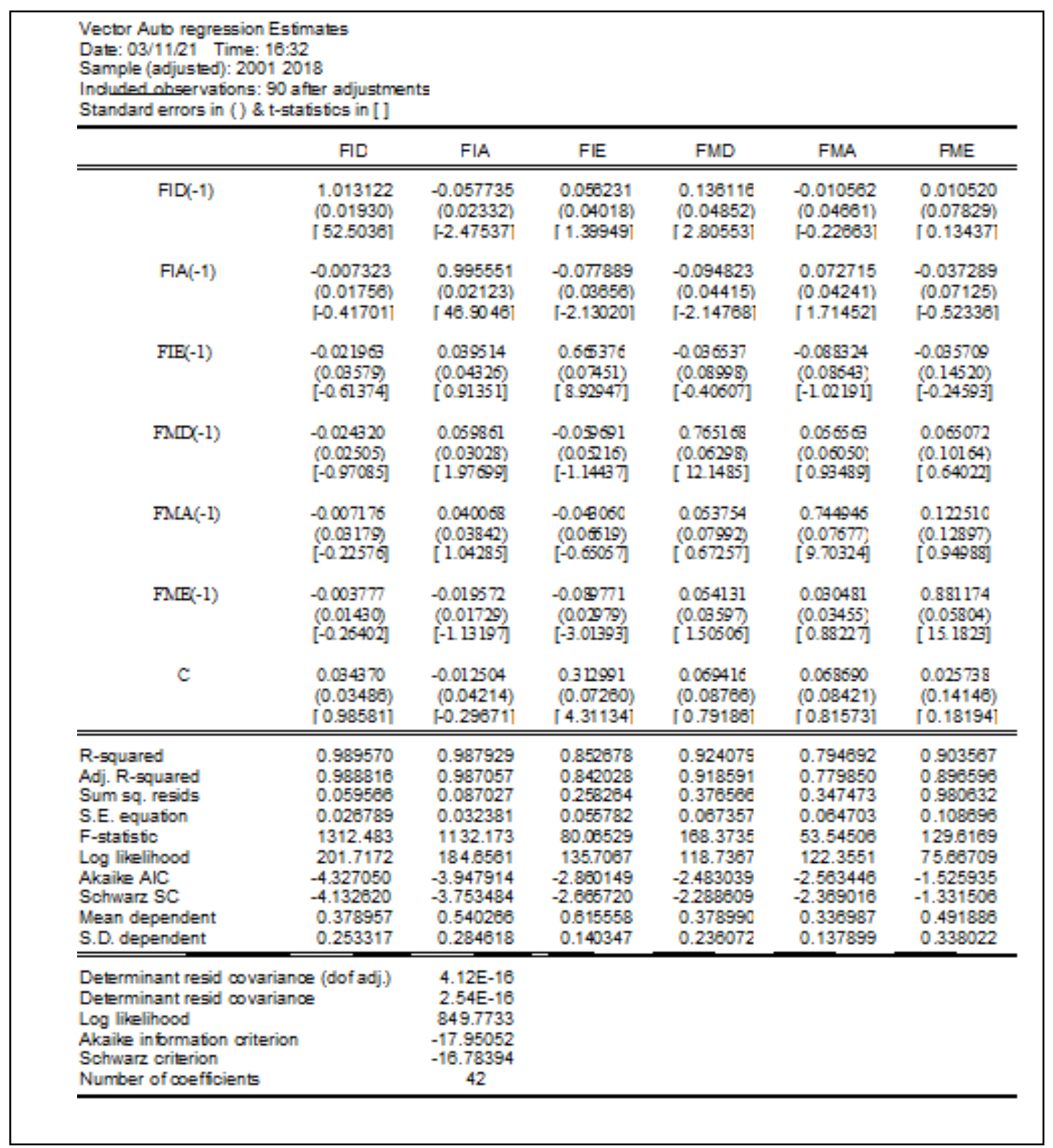

Table 3: VAR Results

The VAR estimates revealed strong endogeneity and exogeneity of all the variables. The coefficientsof t-statistic and percentage increase depicts that FID, FIA, FIE, FMD, FMA and FME had strong self-influence, as their pass realizations associated with 100\%, 99.56\%, 66.54\%, 76.52\%, 74.49\% and 88.12\% increase in FID, FIA, FIE, FMD, FMA and FME respectively on average ceteris paribus. And respective co efficient of determination as represented by $\mathrm{R}$ square of $0.989570,0.987929,0.852678,0.924079,0.794692$ and 0.903567 with adjusted $\mathrm{R}$ of $0.988816,0.987057,0.842028$, 0.918591 , and 0.779850 and 0.896596 respectively. FID had weak positive influence on FIE, FMD, and FMEand weak negative influence on FIA and FMA. All the variables (FIA, FIE, FMD, FMA and FME) had no positive influence on FID as the pass realization of FID was associated with $100 \%$ increase in FID. FIA had weak negative influence on all the variables except FMA. FIE, FMD and FMA had weak positive influence. FIA, FID and FME had weak negative influence on FIAon average ceteris paribus. FIE had weaknegative influence on all the variables except FIA, and all the variables also had negative influence on FIE except FID with relative positive influence. FMD had weak positive influence on FIA and FMA and FME but weak negative influence on FID and FIE. FID had strong positive influence on FMD, FMA and FME had weak positive influence on FMD while FID and FIE recorded weak negative influence. FMA had weak positive influence on FIA, FMD and FME and exhibited weak negative influence on FID and FIE. FIA, FMD and FME had weak positive influence on FMA while, FID and FIE had portrayed weak negative influence on FMA. FME had weak positive influence on FMD and FMA, and weak negative influence on FID, FIA and FIE. Apart from FIA, all variables exhibited weak positive influence on FME. 


\begin{tabular}{|c|c|c|c|c|c|}
\hline \multicolumn{2}{|c|}{ Autocorrelation } & \multicolumn{2}{|c|}{ Heteroskedasticity } & \multicolumn{2}{|c|}{ Normality } \\
\hline F-stat & 1.968697 & Joint & 0.0001 & 1 & 0.0000 \\
\hline \multirow{6}{*}{ Prob } & \multirow{6}{*}{0.0012} & \multirow{6}{*}{$\begin{array}{l}\text { Chi-sq } \\
\text { t }=344.0806 \text { ) }\end{array}$} & 19.17964 & 2 & 0.0453 \\
\hline & & & 29.94163 & 3 & 0.0000 \\
\hline & & & 19.52057 & 4 & 0.5713 \\
\hline & & & 31.54387 & 5 & 0.0031 \\
\hline & & & 20.93165 & 6 & 0.5658 \\
\hline & & & 19.25368 & Joint & 0.4873 \\
\hline
\end{tabular}

Table 4: Summary of Diagnostic Tests

VAR residual serial correlation LM test indicated absence of serial correction at lags 1 to $h$ in both BRICS and MINT. The Normality Tests revealed that out of the six components in BRICS, second, fourth, fifth and sixth variables residuals' were normally distributed. While, all the six MINT componentswere normally distributed. Heteroskedasticity tests at levels and squares for both BRICS and MINT depict presence of Heteroskedasticity.

\begin{tabular}{|c|c|c|c|c|c|c|c|}
\hline \multicolumn{8}{|c|}{ Variance Decomposition of FID: } \\
\hline 1 & 0.026789 & 100.0000 & 0.000000 & 0.000000 & 0.000000 & 0.000000 & 0.000000 \\
\hline 2 & 0.037955 & 99.75940 & $3.13 E-05$ & 0.074277 & 0.144234 & 0.011589 & 0.010465 \\
\hline 3 & 0.046576 & 99.36568 & 0.000288 & 0.174191 & 0.395285 & 0.036545 & 0.028009 \\
\hline 4 & 0.053878 & 98.91749 & 0.001034 & 0.266056 & 0.693359 & 0.071642 & 0.050416 \\
\hline 5 & 0.060331 & 98.46266 & 0.002518 & 0.339737 & 1.003521 & 0.113757 & 0.077806 \\
\hline \multicolumn{8}{|c|}{ Variance Decomposition of FIA: } \\
\hline Period & S.E. & FID & FIA & FIE & FMD & FMA & FME \\
\hline 1 & 0.032381 & 0.002775 & 99.99723 & 0.000000 & 0.000000 & 0.000000 & 0.000000 \\
\hline 2 & 0.045755 & 0.003179 & 98.48186 & 0.108713 & 0.825561 & 0.387287 & 0.193398 \\
\hline 3 & 0.056295 & 0.004704 & 95.93790 & 0.226766 & 2.252056 & 1.028158 & 0.550415 \\
\hline 4 & 0.065441 & 0.008500 & 93.05188 & 0.309909 & 3.910244 & 1.743294 & 0.976177 \\
\hline 5 & 0.073679 & 0.016238 & 90.18848 & 0.356902 & 5.592111 & 2.441587 & 1.404683 \\
\hline \multicolumn{8}{|c|}{ Variance Decomposition of FIE: } \\
\hline Period & S.E. & FID & FIA & FIE & FMD & FMA & FME \\
\hline 1 & 0.055782 & 0.520166 & 1.354145 & 98.12569 & 0.000000 & 0.000000 & 0.000000 \\
\hline 2 & 0.067538 & 0.368659 & 1.761999 & 95.90141 & 0.050034 & 0.050493 & 1.867408 \\
\hline 3 & 0.073535 & 0.331651 & 2.120606 & 91.63526 & 0.175802 & 0.216278 & 5.520400 \\
\hline 4 & 0.077762 & 0.365972 & 2.403838 & 86.28833 & 0.370760 & 0.518987 & 10.05211 \\
\hline 5 & 0.081360 & 0.429547 & 2.611583 & 80.70638 & 0.615191 & 0.941215 & 14.69608 \\
\hline \multicolumn{8}{|c|}{ Variance Decomposition of FMD: } \\
\hline Period & S.E. & FID & FIA & FIE & FMD & FMA & FME \\
\hline 1 & 0.067357 & 7.040856 & 0.363740 & 2.032297 & 90.56311 & 0.000000 & 0.000000 \\
\hline 2 & 0.085041 & 8.315892 & 0.757915 & 2.322225 & 88.07484 & 0.100878 & 0.428250 \\
\hline 3 & 0.094581 & 9.600588 & 1.270994 & 2.611504 & 84.82551 & 0.270327 & 1.421073 \\
\hline 4 & 0.100748 & 10.84643 & 1.864844 & 2.878510 & 81.03540 & 0.456880 & 2.917936 \\
\hline 5 & 0.105365 & 12.02028 & 2.497271 & 3.108213 & 76.95202 & 0.627207 & 4.795009 \\
\hline \multicolumn{8}{|c|}{ Variance Decomposition of FMA: } \\
\hline Period & S.E. & FID & FIA & FIE & FMD & FMA & FME \\
\hline 1 & 0.064703 & 0.880256 & 0.000190 & 0.132051 & 0.332787 & 98.65472 & 0.000000 \\
\hline 2 & 0.080568 & 0.955751 & 0.106050 & 0.260089 & 0.214826 & 98.31200 & 0.151288 \\
\hline 3 & 0.088771 & 0.993011 & 0.322106 & 0.655398 & 0.269017 & 97.16619 & 0.594275 \\
\hline 4 & 0.093892 & 1.002944 & 0.616962 & 1.094916 & 0.460371 & 95.45740 & 1.367409 \\
\hline 5 & 0.097583 & 0.995693 & 0.956822 & 1.475612 & 0.745534 & 93.38656 & 2.439783 \\
\hline \multicolumn{8}{|c|}{ Variance Decomposition of FME: } \\
\hline Period & S.E. & FID & FIA & FIE & FMD & FMA & FME \\
\hline 1 & 0.108696 & 3.004877 & 0.184371 & 0.833301 & 4.876398 & 1.640089 & 89.46096 \\
\hline 2 & 0.143592 & 2.708712 & 0.244036 & 0.678230 & 4.268886 & 1.033399 & 91.06674 \\
\hline 3 & 0.165795 & 2.436250 & 0.303513 & 0.548946 & 3.759013 & 0.790605 & 92.16167 \\
\hline 4 & 0.181878 & 2.194456 & 0.361026 & 0.457724 & 3.342382 & 0.779856 & 92.86455 \\
\hline 5 & 0.194417 & 1.986103 & 0.415672 & 0.405594 & 3.007712 & 0.906572 & 93.27835 \\
\hline
\end{tabular}

Table 5: Cholesky Variance Decomposition Results

All the variables exhibited strong endogeneity and exogeneity both in the short run and long run. There was trace of weak influence from shocks of other variables, as no degree of unexpected variation was produced by innovations from these variables and this was in tandem with the VAR results. In the short run, $100 \%$ and $99.76 \%$ forecast error variance in FID was explained by FID itself, while $99.37 \%, 98.92 \%$ and $98.46 \%$ explained in the long run. This confirms that FIA, FIE, FMD, FMA and FME had weak influence on FID both in the shortrun and long run. FIA 99.997\% and 98.48\% forecast variance in the short run was self-predicted by FIA, 95.94\%, 93.05\% and $90.19 \%$ was also predicted in the long run, confirming that FID, FIE, FMD, FMA and FME had weak influence on FID.98.13\% and 95.90\%forecast error variance was also explained FIE on the short run, and $91.64 \%, 84.29 \%$ and $80.71 \%$ on the long run.14.70\% of FIE was predicted on the 
long run by FME confirming its relative negative influence.However,FMD revealed 90.56\%, and 88.07\% self-prediction in the short run,and $84.83 \%, 81.04 \%$, and $76.95 \%$ on the long run. $8.31 \%$ and $12.02 \%$ forecast error variance in FMD was predicted by FID in the short and long run respectively, confirming weak positive influence of FID on FMD. FMA selfexplained $98.65 \%$ and $98.31 \%$ in the short run, $97.17 \%, 95.46 \%$ and $93.39 \%$ in the long run confirming weak influence of other variables on FMA. 89.46\% and 91.07\% was self-predicted by FME in the short run, 92.16\%, 92.86\% and 93.28\% on the long run, confirming the influence of other variables on FME.

\section{Conclusion/Implcations of Resultand Recommendations}

Generally, indicators of financial system development had strong endogeneity and exogeneity, as independent influence and significant self-predictions were revealedboth in the shortand long run. Implying that movement in the individual components of financial system does not have strong external influence on each other, as all the segmented indicators of financial system development exhibited magnificent independence. Based on the findings, researchers recommends that Central banks of member nations should establish BRICS monetary zone to facilitate cross border effect of financial institutions and markets development in member states, monetary authorities in the BRICS countries should establish financial system development secretariat to harness the component influence of financial institutions and markets depth, access and efficiency in her economic blocand to pursue a robust and innovative financial institutions and markets development framework to complement innovations in the different components of the financial system and provide incentives for the adoption of digital financial system in her emerging economic bloc.

\section{References}

i. Ebiringa, O. T. and Duruibe, S. C. (2015). Financial system development and economic growth: Evidence from Nigeria.American journal of economics, finance and management,1(5),329-335. http://www.aiscience.org/journal/ajefm

ii. Gokhale, V. (2018). The prospects of MINT nations: Testing the efficient market hypothesis. International journal of business quantitative economics and applied management research, 5(3), 16-29.

iii. Guru, B. K. and Yadav, I. S. (2019). Financial development and economic growth: panel evidence from BRICS. Journal of economics, finance and administrative science, 24 (47), 113-126. Doi 10.1108/JEFAS-12-2017-0125

iv. Iheonu, C. O. et al. (2020). Financial sector development and Investment in selected countries of the Economic Community of West African States: Empirical evidence using heterogeneous panel data method. Financial Innovation, 6(29), 1-15. https://doi.org/10.1186/s40854-020-00195-0

v. Majumder, M. G., Ramalingam, N. and Ramudu, P. J. (2019).Modeling dynamic communications between financial development trade and growth: MINT economy. SCMS Journal of Indian Management.

vi. Mugova, S. (2017). Financial sector development and firm growth: Evidence growth in BRICS countries. Risk governance and control: Financial markets and institutions, 7(4), $126-134$. http://doi.org/10.22495/rgc7i4c1art4

vii. McManus, J. (2016). An Economic Perspective of the MINT Nations. Management services, 60(3), $13-19$.

viii. Ohiomu, S. and Oligbi, B. O. (2020). The influence of financial sector development and financial deepening on economic growth: Empirical evidence from Nigeria. IOSR journal of economics and finance, 11(1), 58-67. https://www.researchgate.net/publication/338969004

ix. Osuji, O. (2015). Financial development and economic growth in Nigeria. Journal of Economics and Sustainable Development, 6(20), 26-40. www.iiste.org

x. Sulemana, M. and Dramani, J. B. (2020): Effect of financial sector development and institutions on economic growth in SSA: Does the peculiarities of regional blocs matter? Journal of sustainable finance and investment. Doi:10.1080/20430795.2020.1837500

xi. Sarwar, A. et al. (2020). Financial development, human capital and its impact on economic growth of emerging countries. Asian Journal of Economics and Banking. Doi10.1108/AJEB-06-2020-0015

Sunanda, S. (2018). The BRICS Initiatives towards a new financial architecture: An assessment with some proposals. Research and information system for developing countries, RIS discussion paper number 205.

xiii. Stiglingh, A., Muzindutsi, P. F. and Bezuidenhout, D. V. (2018). An analysis of the relationship between economicgrowth and financial development for BRICS countries. https://www.researchgate.net/publication/286904818

xiv. Zhong, J. and Li, T. (2020). Impact of Financial Development and Its Spatial Spillover Effect on Green Total Factor Productivity: Evidence from 30 Provinces in China. HindawiMathematical Problems in Engineering. https://doi.org/10.1155/2020/5741387 